\title{
Erratum to: Nitrospirillum irinus sp. nov., a diazotrophic bacterium isolated from the rhizosphere soil of Iris and emended description of the genus Nitrospirillum
}

\author{
Eu Jin Chung • Tae Soon Park • Kyung Hyun Kim • \\ Che Ok Jeon • Hae-In Lee • Woo-Suk Chang • \\ Zubair Aslam · Young Ryun Chung
}

Published online: 22 September 2015

(C) Springer International Publishing Switzerland 2015

\section{Erratum to: Antonie van Leeuwenhoek (2015) \\ 108:721-729 \\ DOI 10.1007/s10482-015-0528-x}

In the original publication of the article, the species epithet "irinus" proposed for the taxon represented by strain YC6995 $^{\mathrm{T}}$ has been malformed. The correct name for the taxon should have been proposed as "iridis". The revised description is given below:

\section{Description of Nitrospirillum iridis sp. nov.}

Nitrospirillum iridis ((i'ri.dis. L. gen. n. iridis, of Iris, isolated from the rhizosphere soil of Iris ensata var. spontanea (Makino) Nakai).

The online version of the original article can be found under doi:10.1007/s10482-015-0528-x.

\section{E. J. Chung · T. S. Park · Y. R. Chung $(\square)$}

Division of Applied Life Science (BK 21 Plus), Plant Molecular Biology \& Biotechnology Research Center, Gyeongsang National University, Jinju 660-701, Republic of Korea

e-mail: yrchung@gnu.ac.kr

K. H. Kim - C. O. Jeon

Department of Life Science, Chung-Ang University,

Seoul 156-756, Republic of Korea

H.-I. Lee · W.-S. Chang

Department of Biology, University of Texas-Arlington, Arlington, TX 760194, USA
Gram-negative, rod-shaped, facultatively anaerobic rods with $1.0-1.3 \mu \mathrm{m}$ in width, and $1.8-2.9 \mu \mathrm{m}$ in length. Cells are motile by a single polar flagellum. Colonies on R2A agar are white, and circular with an entire margin. The temperature range for growth is 10-35 ${ }^{\circ} \mathrm{C}$, with optimum growth occurring at $30{ }^{\circ} \mathrm{C}$. The $\mathrm{pH}$ range for growth is 4.0-7.5 with optimum growth at $\mathrm{pH} 7.0$. Cell growth can occur at $0-0.2 \%$ $\mathrm{NaCl}(w / v)$; optimum growth occurs without $\mathrm{NaCl}$. Cells are catalase and oxidase-positive. Cells have the ability to hydrolyze L-tyrosine and Tween 20 , but not Tween 80, carboxylmethyl cellulose, gelatin, and starch. Positive reaction occurs for nitrogen fixation. Using the API50CH kit, D-xylose, L-rhamnose, esculin ferric citrate, salicin, D-cellobiose, D-maltose, D-saccharose, D-trehalose, gentiobiose and D-fucose can be used as sole carbon sources, but not glycerol, erythritol, D-arabinose, L-arabinose, D-ribose,

\section{W.-S. Chang}

Division of Biotechnology, College of Environmental and Bioresource Sciences, Chonbuk National University, Iksan 570-752, Republic of Korea

\section{Z. Aslam}

Department of Agronomy, University of Agriculture, Faisalabad 38040, Pakistan 
D-xylose, L-xylose, D-adonitol, methyl-ß-D-xylopyranoside, D-galactose, D-glucose, D-fructose, D-mannose, L-sorbose, dulcitol, inositol, D-mannitol, D-sorbitol, methyl-a-D-mannopyranoside, methyl- $\alpha$-D-glucopyranoside, $N$-acetylglucosamine, amygdalin, arbutin, Dlactose, D-melibiose, inulin, D-melezitose, D-raffinose, amidon, glycogen, xylitol, D-turanose, D-lyxose, Dtagatose, L-fucose, L-arabitol, D-fucose, L-fucose, Darabitol, L-arabitol, potassium gluconate, potassium 2-ketogluconate and potassium 2-ketogluconate. Enzyme activities for alkaline phosphatase, esterase (C4), esterase lipase (C8), leucine arylamidase, valine arylamidase, cystine arylamidase, trypsin, $\alpha$-chymotrypsin, acid phosphatase, naphthol-AS-BI-phosphohydrolase, $\alpha$-galactosidase, $\beta$-galactosidase, $\beta$-glucuronidase, $\alpha$-glucosidase, $\beta$-glucosidase, $N$ acetyl- $\beta$-glucosaminidase, and $\alpha$-fucosidase are present, but lipase (C14) and $\alpha$-mannosidase are absent using the API ZYM kit. The polar lipids are phosphatidylcholine, phosphatidylethanolamine, phosphatidylglycerol, phosphatidyldimethylethanolamine, and unidentified glycolipids. The major cellular fatty acids are $\mathrm{C}_{18: 1} \omega 7 c, \mathrm{C}_{18: 1} 2-\mathrm{OH}, \mathrm{C}_{16: 0} 3-\mathrm{OH}$ and $\mathrm{C}_{16: 0}$. The major isoprenoid quinone is $\mathrm{Q}-10$. The DNA G+C content of the type strain is $64.1 \mathrm{~mol} \%$.

The type strain, YC6995 ${ }^{\mathrm{T}}\left(=\right.$ KACC $13777^{\mathrm{T}}=\mathrm{DSM}$ $22198^{\mathrm{T}}$ ), was isolated from the rhizosphere soil of Iris ensata var. spontanea (Makino) Nakai inhabiting the wetland on Jiri Mountain, Korea. 